\title{
PERBAIKAN MESIN PENGERING DAUN AFRIKA DI SMKN 1 WONOSARI KABUPATEN MALANG MENGGUNAKAN METODE REVERSE ENGINEERING
}

\author{
Djoko Hari Praswanto ${ }^{*}$, Siswi Astuti ${ }^{2}$, F. Endah Kusuma R. ${ }^{3}$, Fourry Handoko ${ }^{4}$ \\ 1,3 Jurusan Teknik Mesin S-1 Institut Teknologi Nasional Malang \\ ${ }^{2}$ Jurusan Teknik Kimia S-1 Institut Teknologi Nasional Malang \\ ${ }^{4}$ Jurusan Teknik Industri S-2 Institut Teknologi Nasional Malang \\ ${ }^{1}$ Email : djoko@lecturer.itn.ac.id
}

\begin{abstract}
Abstrak : Desa Sumberdem di Kecamatan Wonosari Kabupaten Malang memiliki hasil pertanian berupa tanaman obat -obatan, salah satu contohnya adalah daun Afrika. Tanaman ini digunakan sebagai produk teh untuk dikonsumsi oleh penderita diabetes. SMKN 1 Wonosari merupakan mitra yang memproduksi teh daun afrika. Untuk membuat produk teh daun afrika menggunakan mesin pengering. Mesin pengering milik SMKN 1 Wonosari kurang optimal karena beberapa kendala saat kami menggunakannya. Ditemukan 3 masalah pada saat tim menggunakan mesin pengering milik mitra yaitu letak elemen pemanas kurang optimal sehingga pengeringan daun afrika tidak merata, ujung rak tajam yang dapat menyebabkan kecelakaan kerja dan roda pada alas pengering tidak kuat menahan beban. Solusi permasalahan yang digunakan yaitu perbaikan mesin pengering. Ada 3 metode dalam kegiatan pengabdian masyarakat yang dilakukan untuk mencapai luaran adalah metode pendekatan, metode reverse engineering dan on the job training. Hasil dari kegiatan ini adalah mesin pengering daun afrika dengan menggunakan elemen pemanas pada setiap rak. Mesin pengering dengan daya 1450 watt ini memiliki keunggulan yaitu hasil pengeringan daun afrika dapat merata, waktu pengeringan lebih cepat dan lebih aman digunakan. Pemakaian mesin pengering ini mitra dapat menghemat biaya produksi Rp. 7.403 setiap $4 \mathrm{~kg}$ daun afrika basah.
\end{abstract}

\section{Keyword : Teh Daun Afrika, Reverse Engineering, Mesin Pengering}

\section{Pendahuluan}

Desa Sumberdem merupakan salah satu desa yang terletak di Kecamatan Wonosari Kabupaten Malang. Ditinjau dari tingkat penidikan, penduduk desa Sumberdem sangat bervariasi dan relatif masih rendah. Tercatat 145 orang buta huruf, 161 tidak lulus SD, 2912 orang tamat SD, 543 orang tamat SLTP, 381 orang SLTA, 31 berpendidikan S1 dan S2 sebanyak 1 orang. Selain itu, tingkat pengangguran di desa Sumberdem masih cukup tinggi berkisar antara 6,64\% atau sebanyak 271orang dari angkatan kerja usia 15-55 tahun. Untuk meningkatkan kualitas SDM desa Sumberdem, sekitar 42,12\% KK atau $80,26 \%$ penduduk masih memerlukan pendampingan dan pelatihan tentang kewirausahaan yang memanfaatkan hasil tanaman yang tumbuh secara alami. Tanaman hasil bumi yang tumbuh secara alami di Desa Sumberdem salah satunya tanaman obat - obatan seperti daun afrika, pegagang dan lainnya. Tanaman daun afrika ini dapat dimanfaatkan oleh penderita penyakit diabetes. Daun afrika tersebut diolah menjadi teh celup kemudian dapat diseduh dengan air mendidih. Penderita diabetes dengan mengkonsumsi teh daun afrika ini mengalami penurunan kadar gula yang cenderung normal. Dari hasil analisis kalori, menyeduh teh daun afrika sebanyak $0,2289 \mathrm{kkal} / 100$ gram sampel (Lee et al., 2019). 
Produksi teh daun afrika sebelumnya sudah dilaksanakan oleh tim dari SMKN 1 Wonosari. Produksi teh daun afrika tersebut masih tetap berjalan sampai sekarang. Hal ini merupakan hasil dari kegiatan pendampingan dan pelatihan pada tahun sebelumnya oleh tim pengabdian masyarakat ITN Malang. Dalam proses produksi teh menggunakan teknologi tepat guna berupa mesin pengering (Minh, 2019). Pada mesin pengering daun afrika yang dimiliki SMKN 1 Wonosari, sumber panas dihasilkan dari elemen pemanas yang menggunakan energi listrik. mesin pengering tersebut memiliki rak berjumlah 4 rak dengan model 2 pintu, 1 blower untuk membantu penyebaran udara panas, 2 exhaust fan untuk mengeluarkan kadar air yang terkandung pada daun, 1 elemen pemanas dan dilengkapi pengontrol suhu dan kelembaban didalam ruang pemanas. Waktu pengeringan yang dibutuhkan untuk mengeringkan daun afrika menggunakan mesin pengering ini adalah $\pm 4,5$ jam dengan kapasitas 1350 gram. Sehingga biaya penggunaan mesin pengering tersebut Rp. 9.537 untuk mengeringkan daun afrika 1350 gram pada kondisi daun basah. Proses pengeringan ini pun harus sering dilihat dan daun dibolak balik serta dipindah ke rak yang berbeda. Hal ini dilakukan untuk mempercepat proses pengeringan. Kalau proses tersebut tidak dilakukan, pengeringan daun tidak bisa merata. Pada saat proses pemindahan daun dari rak yang berbeda harus dilakukan secara hati - hati, karena alas rak yang panas dan bagian tepi alas yang tajam dapat mengakibatkan kecelakaan kerja.

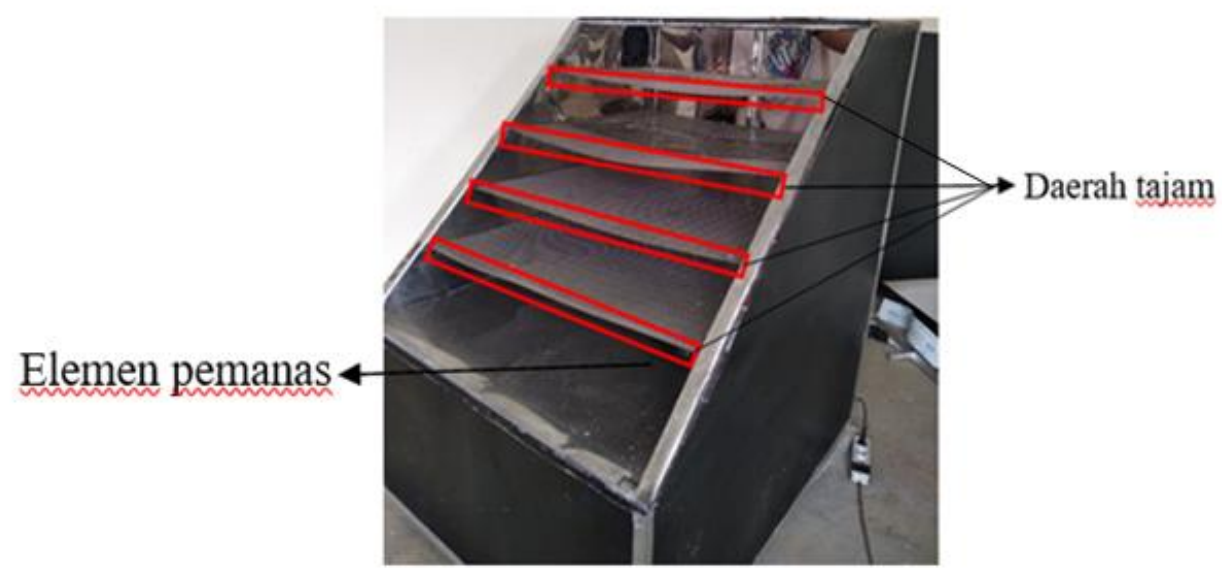

Gambar 1. Kondisi mesin pengering sebelum dilakukan perbaikan 


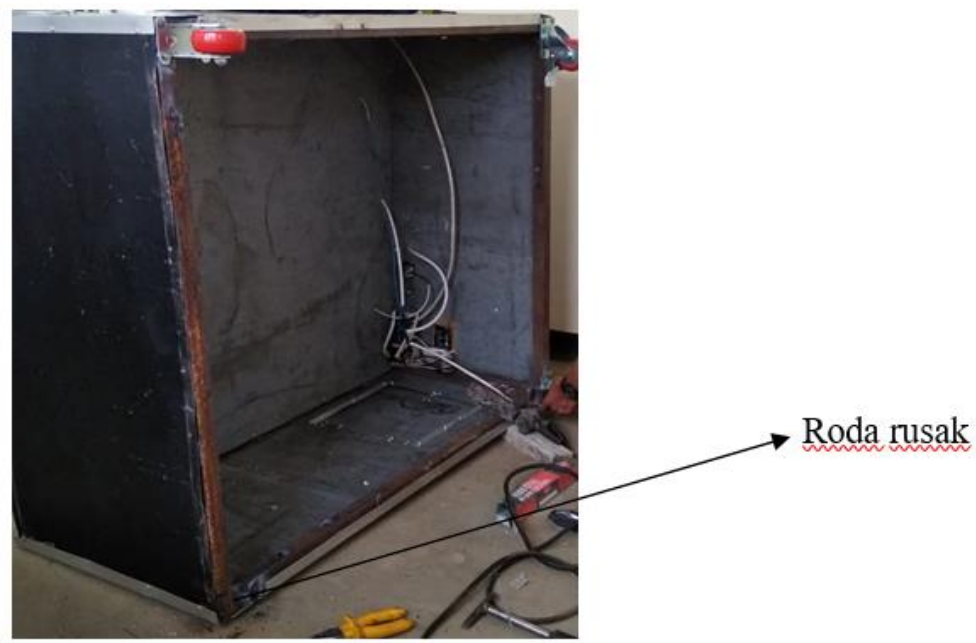

Gambar 2. Kondisi roda yang rusak

Dari hasil kunjungan tim pengabdian masyarakat dapat melihat beberapa masalah yang terjadi di mesin pengering yang dimiliki oleh mitra SMKN 1 Wonosari. Permasalahan pertama yaitu posisi elemen pemanas yang kurang optimal seperti yang ditunjukkan pada gambar 1. Permasalahan ini yang menyebabkan proses pengeringan tidak merata dan membutuhkan waktu lama. Permasalahan kedua adalah di daerah ujung rak yang tidak ada pelapis seperti pada gambar 1 yang ditandai garis merah. Akibat pemotongan alas rak sehingga ujung bekas potongan tajam. Hal ini yang menyebabkan terjadi kecelakaan kerja akibat proses membalikkan dan memindahkan daun afrika ke rak yang lainnya. Permasalahan yang ketiga adalah di alas mesin pengering. Akibat perhitungan beban roda yang kurang optimal sehingga roda tidak mampu menahan berat mesin pengering saat diisi daun afrika sesuai kapasitasnya. Hal ini yang mengakibatkan roda pada alas pengering rusak seperti yang ditunjukkan pada gambar 2 .

Dari ketiga permasalahan pada mesin pengering yang dimiliki oleh SMKN 1 Wonosari, tim pengabdian masyarakat memberikan solusi untuk menyelesaikan permasalah yang dihadapi. Solusi yang paling efisien untuk menyelesaikan masalah pada teknologi tepat guna dengan dilakukannya perbaikan pada mesin pengering menggunakan metode reverse engineering (Praswanto dkk, 2019). Metode reverse engineering memiliki 3 tahapan yaitu, disasembly, asembly dan bachmarking (Ding et al., 2019). Pada sistem pengeringan daun ada 3 metode, pengeringan menggunakan elemen mesin dengan sumber energi listrik, kompor dengan sumber energi gas dan pengeringan absorber dengan mesin pendingin (Brouche et al., 2020). Pada proses pengering daun afrika yang dilakukan mitra menggunakan metode pengeringan elemen pemanas dengan sumber energi listrik. pengeringan menggunakan elemen pemanas, posisi elemen harus sesuai dengan model ruang pengering sehingga pengeringan dapat menyebar secara merata (Djiwo dkk, 2019). Solusi dalam menyelesaikan permasalahan pertama yaitu dengan menambahkan elemen pemanas disetiap rak sehingga pengeringan daun dapat merata dan waktu yang dibutuhkan 
pendek. Pada proses pengeringan, panas akan merambat mulai dari sumber panas ke daerah yang memiliki suhu rendah. Sesuai dengan teori perpindahan panas, laju heat transfer dipengaruhi oleh luasan penampang (Benkhedda et al., 2020). Sehingga dengan memberikan elemen pemanas setiap rak membutuhkan waktu proses pengeringan yang cepat, karena jarak elemen pemanas dengan media daun afrika yang pendek.

Untuk solusi permasalahan yang kedua yaitu ujung alas rak yang tajam dengan memberikan lis cover dari bahan alumunium pada ujung alas rak. Hal ini untuk menghindari kecelakaan kerja saat memasukkan daun kedalam mesin pengering. Sedangkan solusi permasalahan ketiga yaitu mengganti roda dengan kapasitas beban yang lebih besar dari kapasitas mesin pengering. Sehingga saat kapasitas mesin pengering overload masih dapat menahan beban. Dari solusi permasalahan yang akan dilaksanakan oleh tim pengabdian masyarakat diharapkan mampu mengurangi biaya penggunaan mesin pengering dan kecelakaan kerja saat proses pengeringan.

\section{Metode}

Metode pelaksanaan yang digunakan pada kegiatan pengabdian masyarakat agar tercapainya luaran yang diharapkan menggunakan metode pendekatan, metode reverse engineering dan metode pendampingan. Langkah awal kegiatan dimulai dengan metode pendekatan, dimana tim pengabdian melakukan kunjungan ke tempat mitra untuk mengetahui sebab - akibat permasalahan yang terjadi di mitra. Setelah mengetahui beberapa permasalahan yang dihadapi dilakukan analisis situasi dengan menggunakan teori analisis SWOT. Analisis SWOT yang meliputi Strength, Weakness, Opportunity dan Thickness yang dijabarkan pada analisis situasi merupakan dasar dalam menemukan solusi untuk memecahkan permasalahan (Tabah Priangkoso, dkk, 2020).

Setelah mengetahui permasalahan pada mitra yaitu pada mesin pengering, langkah selanjutnya menggunakan metode reverse engineering untuk mengoptimasi kinerja mesin pengering. Reverse engineering merupakan metode yang tepat digunakan dibandingkan metode yang lain, karena untuk mengoptimasi teknologi tepat guna harus melakukan perbaikan pada alat (Wills, 2020). Pada metode ini terdapat 3 tahapan yang dilaksanakan, yaitu :

1. Disasembly

Proses ini merupakan identifikasi alat yang dimiliki mitra untuk mencari kekurangan dan kelebihan. Pada proses ini membongkar alat tersebut dan mengukur dimensi alat dan jenis bahan yang digunakan.

2. Asembly

Pada proses assembly merupakan perakitan ulang setelah identifikasi alat yang sudah ada. Pada proses ini sudah mendapatkan data - data ukur dimensi alat untuk digunakan sebagai bahan proses bachmarking. 
3. Bachmarking

Pada proses bachmarking merupakan tahap akhir, dimana proses ini merupakan rancangan ulang mesin. Dari hasil tahapan sebelumnya didapatkan kelebihan dan kekurangan mesin sehingga dalam proses ini kekurangan yang terdapat di rancang ulang untuk meminimalisir kekurangan.

Sebelum dilakukan perbaikan, perlu mendesain ulang agar saat melakukan perbaikan sesuai dengan konsepnya. Selain itu juga untuk meminimalisir kesalahan pada proses perbaikan (Masud et al., 2019).

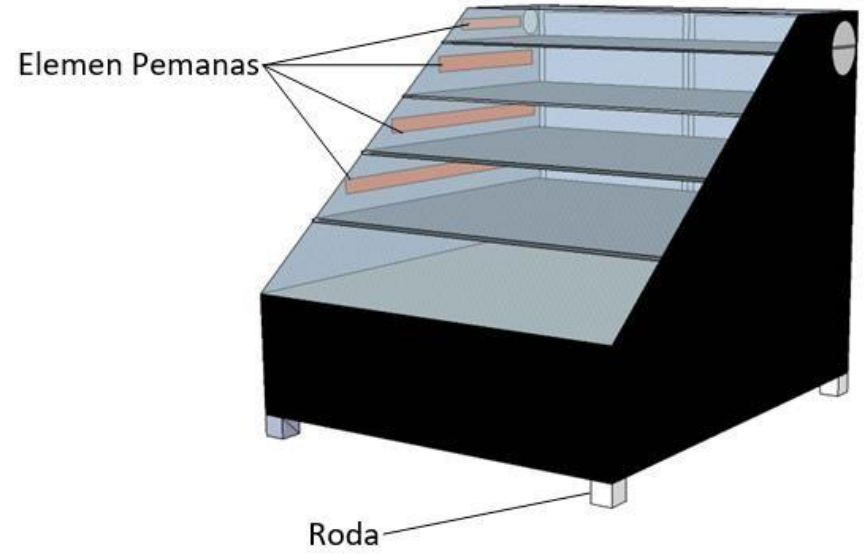

Gambar 3. Desain modifikasi mesin pengering

Setelah metode reverse engineering, proses selanjutnya menggunakan metode pendampingan. Dimana pada proses ini menggunakan sistem on the job training (OJT). On The Job Training (OJT) adalah melatih seseorang untuk mempelajari pekerjaan sambil mengerjakannya. Karyawan memperoleh pelatihan, sehingga dapat memperoleh umpan balik secara langsung dari pelatihnya. Keuntungan dari metode ini adalah relatif tidak mahal, peserta pelatihan bisa belajar sambil tetap menjalankan proses produksi dan tidak memerlukan ruangan khusus (Kafiabad dkk, 2020).

\section{Hasil Karya Utama Dan Pembahasan}

Hasil karya utama dan pembahasan dari kegiatan pengabdian masyarakat yang telah dilakukan bersama mitra SMKN 1 Wonosari sesuai dengan metode pelaksanaan ada 3 tahapan yaitu, tahap pendekatan untuk analisis situasi di mitra, tahap perbaikan dengan menggunakan reverse engineering dan tahap pendampingan dan pelatihan di mitra.

\section{A. Tahap Pendekatan}

Tahap pendekatan ini dilakukan untuk menganalisis situasi didalam mitra. Hasil dari kegiatan ini yaitu menemukan permasalahan yang dihadapi mitra dan solusi yang digunakan untuk menyelesaikan permasalahan mitra. Kegiatan yang dilakukan pada tahap 
ini yaitu kunjungan tim pengabdian masyarakat ke mitra dan diskusi dengan mitra seperti pada gambar 4.
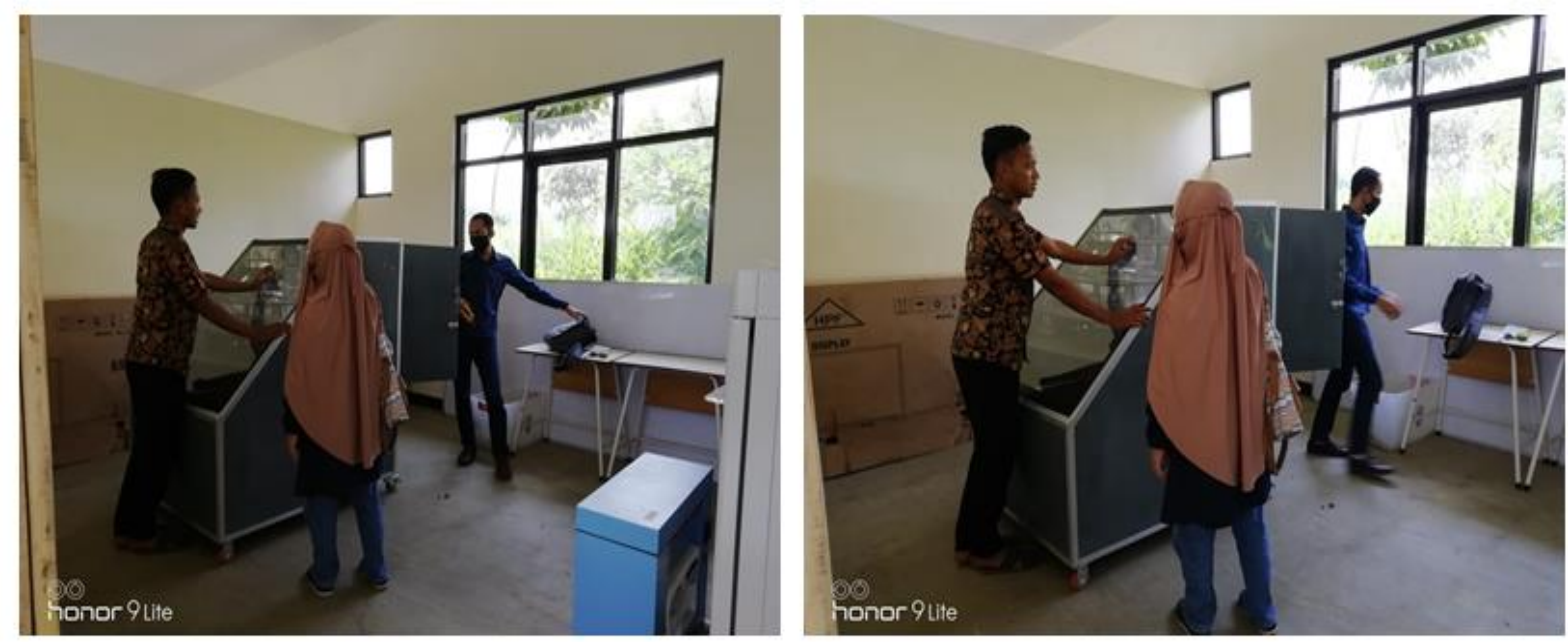

Gambar 4. Kunjungan tim pengabdian ke tempat mitra

Tabel 1. Waktu proses pengeringan daun menggunakan mesin pengering

\begin{tabular}{lc}
\hline Waktu & Proses \\
\hline $\mathbf{0 9 . 0 0}-\mathbf{1 0 . 0 0}$ & Pemanasan awal \\
\hline $\mathbf{1 0 . 0 0}-\mathbf{1 0 . 0 5}$ & Memasukkan daun kedalam mesin pengering \\
\hline $\mathbf{1 0 . 0 5}-\mathbf{1 1 . 0 5}$ & Memindahkan daun dari rak atas ke rak bawah dan sebaliknya \\
\hline $\mathbf{1 1 . 0 5}-\mathbf{1 2 . 0 5}$ & Memindahkan daun dari rak atas ke rak bawah dan sebaliknya \\
\hline $\mathbf{1 2 . 0 5}-\mathbf{1 3 . 0 5}$ & Memindahkan daun dari rak atas ke rak bawah dan sebaliknya \\
\hline $\mathbf{1 3 . 0 5}-\mathbf{1 3 . 2 5}$ & Mengambil daun yang sudah kering \\
\hline & \\
Dari & hasil kunjungan didapatkan data waktu produksi menggunakan mesin \\
pengering seperti pada tabel 1. Dengan menganalisa hasil dari kunjungan ditemukan 3 \\
permasalahan pada mitra yang harus diselesaikan. Permasalahan tersebut antara lain, panas \\
yang tidak merata pada mesin pengering, tajamnya ujung rak yang mengakibatkan \\
kecelakaan kerja dan rusaknya roda pada alas mesin pengering sehingga mesin pengering \\
tidak dapat dipindah tempat. Dengan ditemukannya 3 permasalahan tersebut dilakukan \\
diskusi untuk menemukan solusi dalam menyelesaikan permasalahan. Solusi yang \\
digunakan untuk menyelesaikan permasalahan pada mesin pengering yaitu dilakukannya \\
perbaikan pada mesin pengering dengan menggunakan metode reverse engineering. Dari \\
hasil diskusi kemudian dilakukan re-design pada mesin pengering seperti yang ditunjukkan \\
pada gambar 3 diatas.
\end{tabular}




\section{B. Tahap Perbaikan}

Setalah re-design mesin pengering pada mitra, tahap selanjutnya melakukan perbaikan pada mesin pengering. Pada proses perbaikan terdapat 3 pengerjaan yang dilakukan yaitu, perbaikan roda pada alas mesin pengering, perbaikan ujung rak yang tajam dan perbaikan letak elemen pemanas. Pengerjaan pertama yang dilakukan perbaikan roda, dengan mengganti roda pada alas mesin pengering dan membuatkan rangka roda yang disambungkan ke bagian alas mesin pengering seperti yang ditunjukkan gambar 5 . Penyambungan rangka roda ke bagian alas mesin pengering menggunakan sambungan las.
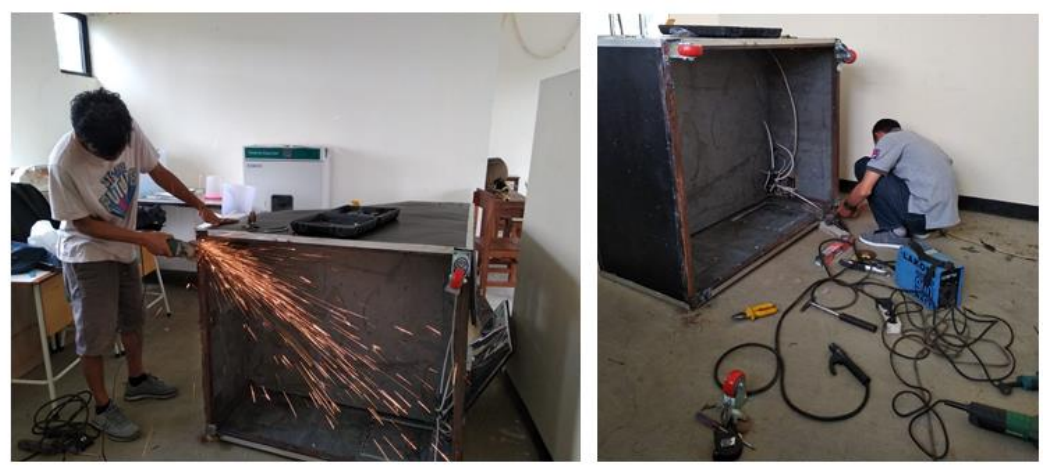

Gambar 5. Pengerjaan perbaikan roda pada alas mesin pengering

Setelah proses pengerjaan pertama selesai, kemudian melakukan pengerjaan kedua yaitu perbaikan ujung rak yang tajam. Pada perbaikan ujung rak yang tajam dilakukan grinding halus menggunakan mesin gerinda. Setelah ujung rak halus, dipasangkan lis dari bahan alumunium seperti yang ditunjukkan gambar 6 .

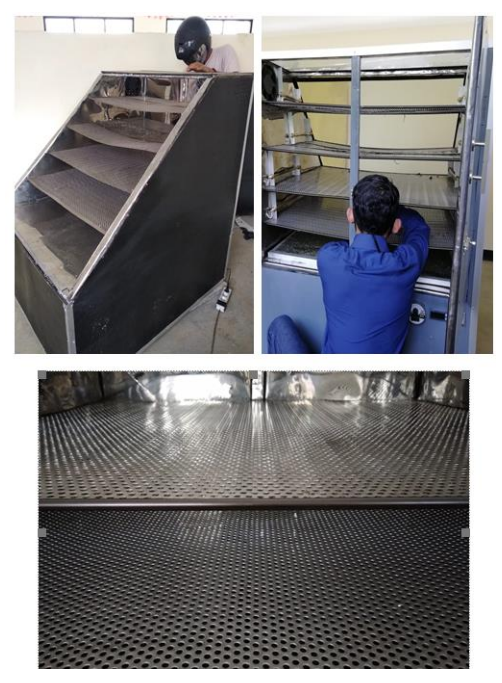

Gambar 6. Proses perbaikan ujung rak 
Setelah proses perbaikan ujung rak selesai, kemudian dilakukan pengerjaan perbaikan elemen pemanas. Pada mesin pengering sebelumnya menggunakan elemen pemanas tunggal yang letaknya berada di rak bagian bawah. Setelah dilakukan re-design elemen pemanas diletakkan disetiap rak sehingga menambah jumlah elemen pemanas. Hal ini dilakukan agar pengeringan daun disetiap rak hasilnya akan sama. Pada proses pengerjaan perbaikan elemen pemanas langkah pertama yang dilakukan dengan membuka cover mesin pengering, kemudian memasang elemen pemanas disetiap rak, setelah itu merangkai rangkaian listrik pada elemen pemanas dan yang terakhir memasang kembali cover pada mesin pengering seperti pada gambar 7 .
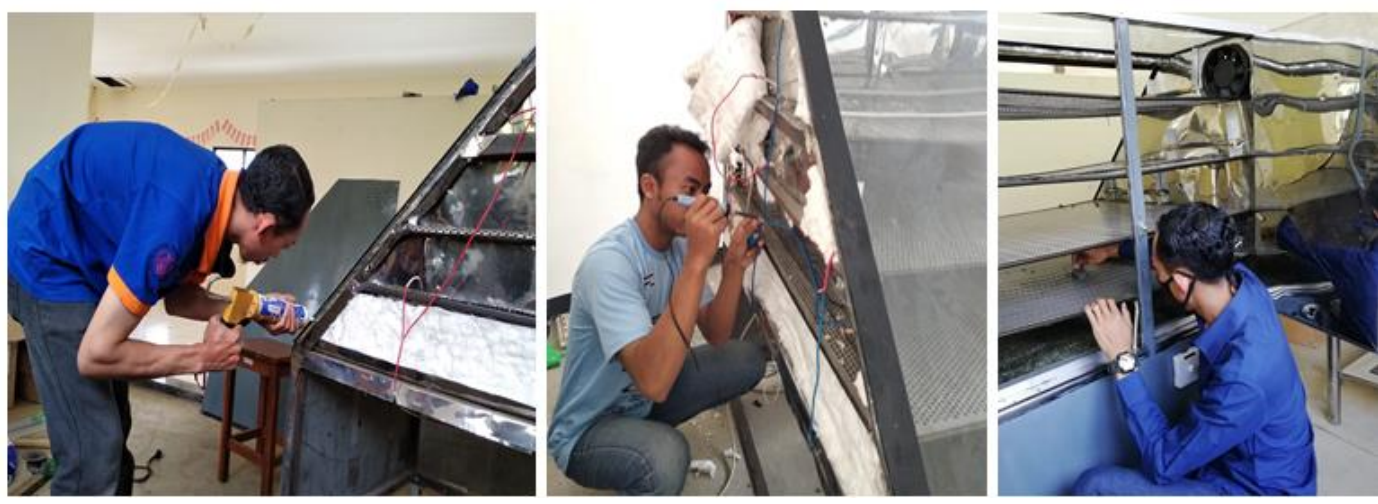

Gambar 7. Proses perbaikan elemen pemanas

Pada rangkaian elemen pemanas yang digunakan adalah rangkaian seri dan paralel. Elemen pemanas yang digunakan pada mesin pengering yaitu 8 elemen pemanas dengan total daya yang dibutuhkan 1450 watt. Dibandingkan dengan mesin pengering sebelumnya menggunakan 1 elemen pemanas dengan daya yang dibutuhkan 1300 watt, pada mesin pengering setelah dilakukan perbaikan mengalami peningkatan daya menjadi 1450 watt. Kalau dilihat dari jumlah daya yang dibutuhkan pada mesin pengering setelah dilakukan perbaikan biaya listrik akan bertambah tetapi dari hasil uji coba biaya listrik semakin sedikit karena waktu pemanasan yang cepat dibandingkan menggunakan mesin pengering sebelumnya.

Hasil pada tahap perbaikan ini adalah berupa mesin pengering seperti gambar 8 dengan spesifikasi sebagai berikut.

Spesifikasi mesin pengering :

Jenis pemanas : elemen panas

Sumber energi $\quad:$ Listrik $220 \mathrm{~V}$ ac

Jumlah elemen pemanas $\quad: 8$ elemen 
Daya

Jenis rak

Jumlah rak

Kapasitas
: 1450 watt

: Stainless

: 4 rak

: $4 \mathrm{~kg}$ daun basah
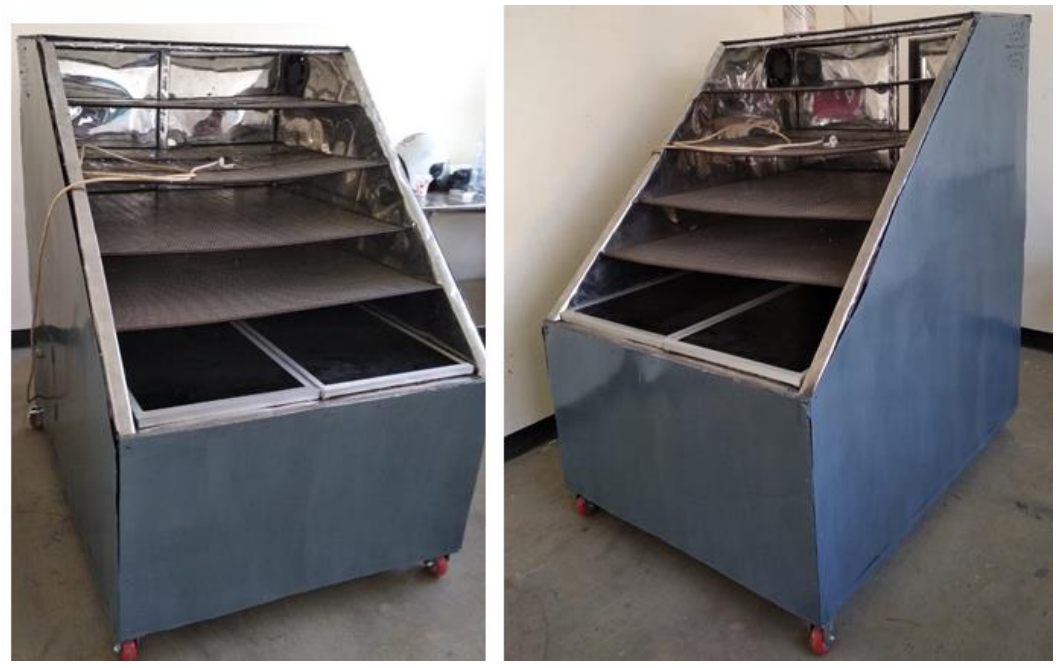

Gambar 8. Mesin pengering setelah perbaikan

Keunggulan dari mesin pengering tersebut adalah waktu proses pengeringan cepat sehingga biaya listrik yang dibutuhkan sedikit, pengeringan setiap daun merata dan daya listrik yang dibutuhkan relatif kecil dengan kapasitas $4 \mathrm{~kg}$ daun basah dibanding mesin pengering lainnya dengan kapasitas sama. Tetapi mesin pengering tersebut masih ada kelemahan yaitu dari bentuk mesin pengering. Bentuk mesin pengering trapesium seperti ini membuat kapasitas setiap rak berbeda. Sehingga daya elemen pemanas harus dibuat berbeda agar pengeringan daun di setiap rak sama.

\section{Tahap Pendampingan dan Pelatihan}

Setelah proses perbaikan pada mesin pengering, tahap selanjutnya pendampingan dan pelatihan dalam menggunakan mesin pengering dan pembuatan teh celup dari daun afrika. Pelatihan yang pertama dilakukan seperti gambar 9 yaitu cara pengoperasian mesin pengering dengan langkah - langkah sebagai berikut :

1. Set up termokontrol pada temperatur $50^{\circ} \mathrm{C}$.

2. Tunggu sampai indikator termometer menunjukkan angka $50{ }^{\circ} \mathrm{C}$ (waktu yang dibutuhkan 10-15 menit) 
3. Masukkan daun afrika basah kedalam mesin pengering.

4. Setelah waktu 15 menit, hidupkan blower agar kandungan air didalam mesin pengering keluar dari ruang pengering.

5. Setelah waktu 45 menit, cek daun afrika apabila sudah kering dikeluarkan dari mesin pengering dan dimasukkan kedalam wadah steril.
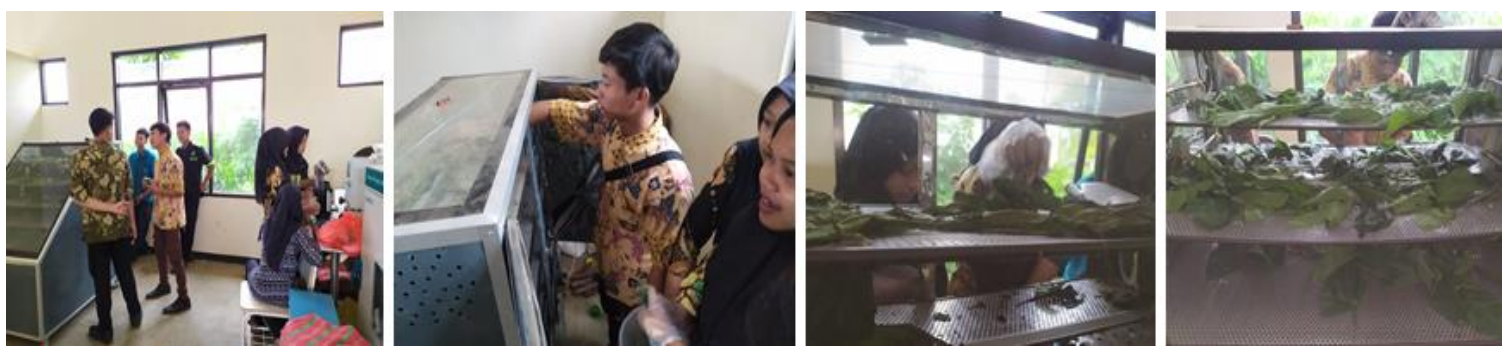

Gambar 9 Kegiatan pendampingan dan pelatihan di mitra

Setelah proses pengeringan, daun afrika yang sudah kering dikeluarkan dari dalam mesin pengering kemudian di masukkan kedalam wadah steril. Setelah itu daun afrika dikemas menggunakan kantong saringan dengan sendok takar. Kemudian kantong saringan tersebut disealer menggunakan mesin sealer. Produk jadi dari proses produksi ini berupa teh celup dari daun afrika seperti pada gambar 10.
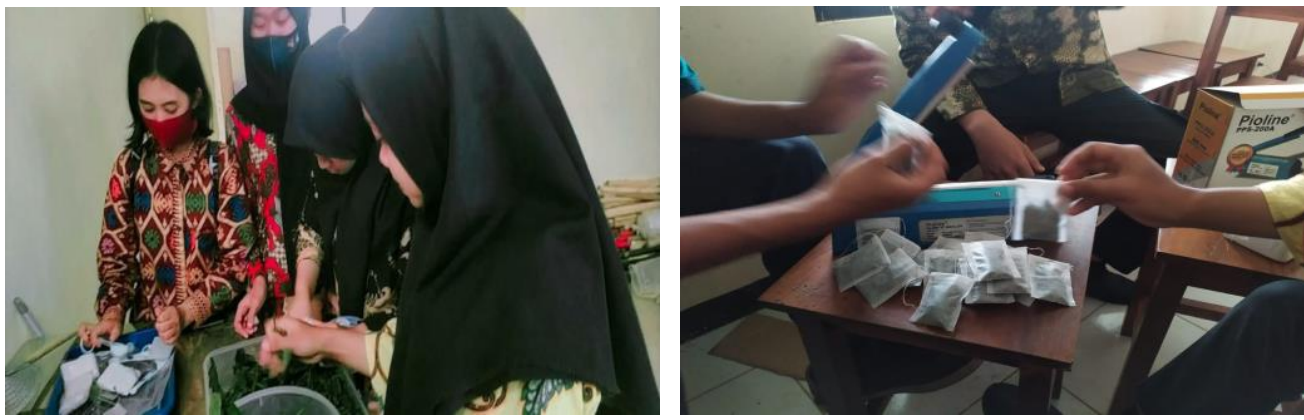

Gambar 10. Pengemasan teh celup daun afrika

Dari hasil pelatihan di mitra, didapatkan tabel waktu proses untuk membandingkan dengan waktu proses menggunakan mesin pengering sebelum dilakukan perbaikan.

Tabel 2. Waktu proses pengeringan menggunakan mesin pengering sudah dilakukan perbaikan 


\begin{tabular}{cc}
\hline $\mathbf{0 9 . 1 0}-09.15$ & Memasukkan daun kedalam mesin pengering \\
\hline $\mathbf{0 9 . 1 5}-\mathbf{0 9 . 3 0}$ & Proses pengeringan daun afrika \\
\hline $\mathbf{0 9 . 3 0}-\mathbf{0 9 . 4 5}$ & Blower dihidupkan dan daun afrika dibolak balik \\
\hline $\mathbf{1 0 . 0 0}$ & Daun afrika kering dikeluarkan dari mesin pengering \\
\hline
\end{tabular}

Pada tabel 2 menunjukkan waktu proses pengeringan menggunakan mesin pengering yang sudah dilakukan perbaikan membutuhkan waktu 60 menit. Sedangkan proses pengeringan menggunakan mesin pengering sebelumnya membutuhkan waktu 4,5 jam. Jika dilihat dari daya yang dibutuhkan mesin pengering yang sudah dilakukan perbaikan membutuhkan 1450 watt sedangkan mesin pengering sebelumnya 1300 watt. Dari data waktu proses dan daya listrik yang dibutuhkan maka biaya listrik dapat diketahui. Biaya listrik yang dibutuhkan pada mesin pengering setelah perbaikan adalah Rp. 2.127, sedangkan mesin pengering sebelumnya membutuhkan biaya listrik Rp. 9.530 dengan kapasitas yang sama. Sehingga dapat disimpulkan bahwa mesin pengering setelah dilakukan perbaikan dapat menghemat biaya listrik meskipun daya listrik yang dibutuhkan besar. Dari hasil kegiatan pengabdian ini, mitra dapat menghemat biaya produksi sebesar Rp. 7.403 .

\section{Kesimpulan}

Dari hasil kegiatan pengabdian masyarakat di mitra SMKN 01 Wonosari Kabupaten Malang menghasilkan teknologi tepat guna berupa mesin pengering daun afrika. Mesin pengering dengan daya 1450 watt ini memiliki keunggulan yaitu hasil pengeringan daun afrika dapat merata, waktu pengeringan cepat dan lebih aman digunakan. Dengan menggunakan mesin pengering setelah dilakukan perbaikan ini, mitra dapat menghemat biaya produksi sebesar Rp. 7.403 .

\section{Daftar Pustaka}

Benkhedda, M. et al. (2020) 'Convective heat transfer performance of hybrid nanofluid in a horizontal pipe considering nanoparticles shapes effect', Journal of Thermal Analysis and Calorimetry, 140(1), pp. 411-425. doi: 10.1007/s10973-019-08836-y.

Brouche, M. et al. (2020) 'ScienceDirect Solar drying simulation of different products: Lebanese case', Energy Reports, 6(June), pp. 548-564. doi: 10.1016/j.egyr.2020.09.032.

Ding, Z. et al. (2019) 'A digital construction framework integrating building information modeling and reverse engineering technologies for renovation projects', Automation in Construction, 102(February), pp. 45-58. doi: 10.1016/j.autcon.2019.02.012.

Djiwo, S., Pohan, G. A. and Praswanto, D. H. (2019) 'Dryer Segel Botol Plastik Untuk Peningkatan Kwalitas Kemasan Botol Vitamin Unggas Di Kecamatan Purwosari 
Kabupaten Pasuruan', Jurnal Aplikasi Dan Inovasi Ipteks 'Soliditas' (J-Solid), 1(2), p. 84. doi: $10.31328 /$ js.v1i2.901.

Kafiabad, S. T., Kazemi Zanjani, M. and Nourelfath, M. (2020) 'Integrated planning of operations and on-job training in maintenance logistics networks', Reliability Engineering and System Safety, 199. doi: 10.1016/j.ress.2020.106922.

Lee, R. E. et al. (2019) 'African-Stevia Leaves Herbal Tea as a Low Calorie Antioxidant Source', European Journal of Engineering Research and Science, 4(12), pp. 57-64. doi: 10.24018/ejers.2019.4.12.1462.

Masud, M. H. et al. (2019) 'CFD analysis of a tube-in-tube heat exchanger to recover waste heat for food drying', International Journal of Energy and Water Resources, 3(3), pp. 169-186. doi: 10.1007/s42108-019-00032-w.

Minh, N. P. (2019) 'Herbal tea production from peperomia pellucida leaf', Plant Archives, 19, pp. 449-451.

Praswanto, D. H., Djiwo, S. and Setyawan, E. Y. (2019) 'Perancangan Mesin Penggiling Bumbu Pecel Menggunakan Penggerak Motor Listrik Dengan Metode Reverse Engineering', Jurnal Aplikasi Dan Inovasi Ipteks 'Soliditas' (J-Solid), 2(1), p. 11. doi: 10.31328/js.v2i1.1283.

Tabah Priangkoso, Darmanto, Ernawati Budi Astuti, Laeli Kurniasari, dan I. H. (2020) 'Analisa Swot Pada Usaha Produksi Slondok Puyur Di Sumurarum Kecamatan Grabag Kabupaten Magelang', Abdimas Unwahas, 5(1), pp. 1-7.

Wills, I. (2020) Thomas Edison: Success and Innovation through Failure. Edited by A. Stephen Gaukroger, University of Sydney. Sydney, NSW, Australia: School of History and Philosophy of ScienceUniversity of Sydney. Available at: https://www.amazon.com.au/Thomas-Edison-Success-Innovation-Philosophyebook/dp/B083FZ6W1Y. 